\title{
Effect of Self-Control in Student Behavior Consumptive Study Program Guidance and Counseling Christian University Indonesia
}

\author{
Renatha Ernawati
}

\author{
Christian Universitty of Indoneisa, Jakarta, Indonesia \\ renatha_silitonga@yahoo.com
}

\begin{abstract}
This study aims to determine how much self-control influence on consumer behavior Student Guidance and Counselling Study Program Universitas Kristen Indonesia. Respondents in this study amounted to 50 students, the data collection methods used is by using a questionnaire with a number of question / statement of 60 grains and analyzed using simple regression analysis and correlation coefficient analysis to determine the level of correlation between the variables of Self-Control (X) to variable Consumer behavior (Y). Based on a simple regression test results, obtained by the equation $\mathrm{Y}=49.40$ to 0.109 . This equation shows that the coefficient value of self-control influence of $\mathrm{a}=49.40$ means that when self-control increases, the consumer behavior decreased by $b=0.109$ at 49.40 constants.
\end{abstract}

Keywords: Self-control, consumer behavior, student

\section{INTRODUCTION}

In the 4.0 era is now spending can no longer be separated from consumption activities, each person has their life needs (Pretty, 2013). These needs can be met in a manner that is different. Most needs met with a reasonable but there are also excessive. It causes people to behave consumptive. Consumer behavior as it occurs in almost all levels of society, both women and men, parents to children. Especially consumer behavior was much struck among teenagers especially those for students.

Thursday, November 15th, 2018 at 14:00 to $16: 30$ $\mathrm{pm}$. The authors conducted a survey and interviews in five students in the department of Guidance and Counseling Christian University of Indonesia. Based on surveys and interviews, according to three out of five students, said the monthly cash they receive it less to meet the needs of every month, they claimed to always ask for extra money in the middle of the month to their parents. This was due to three students had had similar habits such as if they went to the Mall and see the goods are attractive, embossed feel like to have in their minds. Even if they have more pocket money they use to buy goods/clothing is a trend they want. They say that in addition to fulfilling the desire, that they do merely to make it look not outdated and appear more attractive and confident. On the other hand they are aware of the behavior / habits that make them become wasteful and can not save. Meanwhile, according to two other students, claiming that the money given by parents is sufficient to meet their needs each month. Based on survey results and interviews, consumer behavior is very interesting to study the students remember the students actually do not yet have the financial ability to meet their needs.

Self-control is an individual's ability to read the situation in the sensitivity of themselves and their surroundings as well as the ability to control and manage behavioral factors in accordance with the conditions to present themselves in socializing (Cofer, 1965; Torrance and Brehm, 1968). Ability to control behavior, the tendency to attract attention, the desire to change the behavior to conform to someone else, always comfortable with other people, shut down his feelings.

Self-control is closely related to emotional control individuals. Three criteria emotion by individuals to steer towards the better, as follows: to exercise selfcontrol that can be accepted socially, can understand how much control is needed to satisfy their needs and appropriate the expectations of society, to assess the situation critically before deciding how to respond and react to the situation (Brown, 2008; Håkansson, 2011; Hurlock E., 2012).

In line with the notions of self control above, it can be concluded that self-control is an attempt to control 
their behavior and respond or decide an action with regard to all impact or the consequences will be.

Self-control with personal control, which controls the behavior, cognitive control, and control over the decisions (Averill, 1973). Aspects of the ability to control the behavior, stimulus control capabilities, the ability to anticipate an event or events, the ability to interpret the event or events and the ability to take decisions.

Based on the above, it is concluded that that can influence self-control is internal or inner factors affect an individual in controlling his behavior and external factors beyond the human self or high or low also affect self-control that exist in a person / individual.

Self-control has a major role for the formation of a good and constructive behavior, self-control function is to align personal desires (self-interest) with temptation (Gul and Pesendorfer, 2004). The ability to control one's self-centered desires and avoid the temptation was very instrumental in the formation of good behavior. There is a human tendency in the child to behave as they please, there is a tendency for the child against the rules, disobedient to parents and follow their own accord. Lazy to study, cheat, do not do homework, go home late at night, to act arbitrarily and other deviant behaviors are temptations that interfere with the child. The temptation can be resistedwith good self-control.

The behavior of the consumer is a behavior that is not based on any purchase rational considerations, but because of a desire that has reached a level that is no longer rational (Glanz et al., 2014; Saito, 2009; Thaler, 1980). The behavior of the consumer is an individual's behavior is influenced by sociological factors in his life that was shown to consume excessive or wasteful and unplanned against goods and services that are less or even not necessary (Andorfer and Liebe, 2013; De Mooij, 2019). Meanwhile, consumer behavior is a conscious act without being followed by the purchase planning and the absence of a sense of urgency or fundamental consideration whether such purchases as a mere wish fulfillment that is driven by the individual's social interaction (Paraswati, 1997).

Based on the above definition-definition, it can be concluded that consumer behavior is the activity of purchasing an excess of goods and services. Where the purchase was made with consideration of the unreasonable and prioritize wants rather than the benefit or need of the goods. The goods are the result of the dark eyes of individuals who are not conquered worldly desires and do not have good self-control and inability to sort out which is a priority and that is just for sheer luxury, so classy seen by others.

\section{METHOD}

The research was conducted at the Indonesian Christian University (UKI) Jl. Maj Sutoyo No. 2 Cawang, East Jakarta, Jakarta 13630, with subjects penelitian are students Prodi Guidance and Counseling. This study was to analyze how much self-control influence on consumer behavior study program student guidance and counseling Indonesian Christian University (UKI). This study uses a quantitative method or approach. The method emphasizes the use of numbers taken from a questionnaire in the scatterplot to respondents. This method is also called the method of discovery, because with this method discovered and developed a variety of new science and technology. This method is called quantitative methods for data and research in the form of figures and statistical analysis using. Survey method is the method used to obtain data from a particular place is natural (not artificial), but researchers do treatment in the collection of data, for example by circulating questionnaires, tests, structured interviews and so on (Sugiyono, 2016, 2010).

Data collection method is a technique used to obtain the data needed in research, data collection can be done in a variety of settings, a variety of sources. The collectionthe data the researchers used a questionnaire or questionnaires, interviews and documentation. Data collection techniques used in this study using a Likert scale. Likert scale is a scale which is in use to measure attitudes, opinions and perceptions person or a group of social phenomenon (Creswell, 2012).

Data analysis is the process of simplification of the data in a form that is easy to interpret. In analyzing the data, to determine whether or not self-control influence on consumer behavior fifth semester student guidance and counseling courses Indonesian Christian University researchers used rumus Product Moment.

\section{RESULT AND DISCUSSION}

The number of respondents in this study is 50 people. The questionnaire can be identified based on the characteristics of the respondents in this study is based on the characteristics of sex.

The instrument used in this study was a questionnaire / questionnaire. Questionnaire test was carried out on 50 respondents. Based on the results of the 60 statements on the validity of the questionnaire, 40 stated Valid. While the reliability test is the extent to which the results of measurements of the same object will generate the same data (Sugiyono, 2016). Test reliability of the questionnaire was calculated $\left(\mathrm{r}_{11}\right)$, if $r_{11}>0.70$ then declared reliable and if $r_{11}<0.70$ it is not reliable. After calculating the reliability of the 60 
item self-control variable (X), which contains 30 items declared valid questions 20 questions and 10 statements is invalid, obtained as a result of calculation r11 at 0.759 . In the variable consumer behavior $(y)$ containing 30 grains statement, 20 declared invalid and a statement is declared invalid,

\subsection{Simple Linear Regression Analysis}

Used to analyze the influence of several independent variables or dependent $(\mathrm{X})$ to the dependent or independent variable (Y) together. The simple linear regression calculation in this assessment are as follows:

$y=a+b x$

Information:

$y \quad$ : Subjects in the predicted dependent variable

$a$ : The price of $\mathrm{Y}$ when $\mathrm{X}=0$ (constant)

$b$ : Figures direction or regression coefficient, which indicates the number increase or decrease in the dependent variable based on variable independent. When the $\mathrm{b}(+)$ then go up, and if $\mathrm{b}$ (-) then a decline.

$x$ : The subject of the independent variables that have a certain value.

To search for a value using the following formula: $a=\frac{\left(\sum y\right)\left(\sum x^{2}\right)-\left(\sum x\right)\left(\sum x y\right)}{n\left(\sum x^{2}\right)-\left(\sum x\right)^{2}}$

It will obtain the following calculation:

$\mathrm{a}=\frac{(2764)(144976)-(2678)(148209)}{50(144976)-(2678)^{2}}=49,40$

Next calculate the value of $b$, with the following formula:

$$
b=\frac{n\left(\sum x y\right)-\left(\sum x\right)\left(\sum y\right)}{n\left(\sum x^{2}\right)-\left(\sum x\right)^{2}}
$$

It will obtain the following calculation:

b $=\frac{50(148209)-(2678)(2764)}{50(144976)-(2678)^{2}}=\frac{(7410450-7401992)}{(7248800-7171684)}$

$$
=\frac{8458}{77116}=0,109
$$

From the above regression calculation a value of 49.40 and the value of $b$ of 0.109 then formed $a$ regression equation as follows:

$y=a+b x$

$y=49.40+0,109 x$

From the results of the regression analysis on $a=$ 49.40 and $b=0.109$ indicates a positive value on selfcontrol and negative variables in consumer behavior.

\subsection{Analysis Correlation Coefficient}

Analysis of the correlation coefficient is used to measure how much self-control relationship to consumer behavior. To search for such relationships, use the following formula:

$$
\begin{aligned}
\mathrm{r} & =\frac{n\left(\sum x y\right)-\left(\sum x\right)\left(\sum y\right)}{\sqrt{\left.\left(n \sum x^{2}\right)-\left(\sum x\right) 2\left(n \sum y\right)-\left(\sum x\right)^{2}\right)}} \\
\mathrm{r} & =\frac{50(1438209)-(2678)(2764)}{\left(50(144976)-(2678)^{2}\left(50(154136)-(2764)^{2}\right.\right.}=0,84
\end{aligned}
$$

Based on the analysis above using the Pearson product moment correlation $\mathrm{r} x y$ value obtained by 0.84. In accordance with the interpretation of the correlation coefficient of this case shows that the strength of the relationship between self-control (X) with the consumer behavior (Y) 0.84 , which means there is a very strong positive influence between the controls themselves against consumer behavior fifth semester student guidance and counseling courses Universities Kristen Indonesia.

\subsection{Determinant coefficient analysis}

The next stage is to calculate the determinant coefficient analysis using the formula:

$$
K D=r^{2} \times 100 \%
$$

It will obtain the following calculation:

$\mathrm{r}=0.84$

$$
\begin{aligned}
& K D=(0,84)^{2} \times 100 \% \\
& K D=76,56 \%
\end{aligned}
$$

From the above determination coefficient calculation values obtained $76.56 \%$. This suggests that self-control influence on consumer behavior fifth semester student guidance and counseling courses Christian University of Indonesia at $76,56 \%$. While the remaining $23.44 \%$ influenced by other variables.

\subsection{Hypothesis testing}

Hypothesis testing prove the hypothesis (H0) Or alternative hypothesis is accepted, the next step is to compare the count $r \mathrm{r}$ table. To prove the magnitude of the correlation back to the consumer behavior of self control, $t$ test. The calculation of significance test $(t$ test) is as follows:

Counting $\mathrm{t}$

$$
\begin{aligned}
& \mathrm{t}=\frac{r \sqrt{n-2}}{\sqrt{1-r^{2}}} \\
& \mathrm{t}=\frac{0,84 \sqrt{50-2}}{\sqrt{1-0,84}} \\
& \mathrm{t}=10.714
\end{aligned}
$$




\section{Calculating t table}

After the big unknown $t$ arithmetic, then $t$ compared to the value of t table. A significant level of error that is used is $(\hat{\mathrm{I}} \pm)=5 \%$ test two parties with degrees of freedom $(\mathrm{df})=\mathrm{n}-2$, which is where the critical value of testing may be obtained from $\mathrm{t}$ distribution table with the following formula:

$$
\begin{aligned}
& \hat{\mathrm{I}} \pm=5 \% \\
& =0.05 \\
& \mathrm{dk}=\mathrm{n}-2=50-2=48 \\
& =0.235
\end{aligned}
$$

For t table of interpolation, ie 0.235

Ho accepted if $\mathrm{t}<\mathrm{t}$ table or $1.072<0.235$

Ha accepted if $\mathrm{t}>\mathrm{t}$ table or $1.072>0.235$

From the test results showed that table with $\hat{\mathrm{I}}$ $\pm=5 \%$ to test the two parties $(\mathrm{df})=\mathrm{n}-2$ is 0.235 from the calculation, tarithmetic $>\mathrm{T}$ table or $1.072>0.235$ thus Ha Ho accepted and rejected, then there is the effect of variable $\mathrm{X}$ disumpulkan (self control) to variable $\mathrm{Y}$ (consumer behavior) to the students of guidance and counseling Christian University of Indonesia.

\subsection{Interpretation of the results of the study/discussion}

Based on the above results, obtained by the calculation as follows:

a. Based on the regression test results, obtained by the equation $\mathrm{Y}=49.40$ to 0.109 . This equation shows that the coefficient value of self-control influence of $\mathrm{a}=49.40$ means that when self-control increases, the decrease of consumer behavior on a constant $b=0.10949 .40$

b. Correlation analysis, the result $\mathrm{r}$ of 0.84 is in the interval 0.80 to 1.00 , which means self-control influence on consumer behavior is very strong.

c. Based on the calculation coefficient of determination (KD) obtained yield was $76.56 \%$, which indicates self-control variables contribute in consumer behavior amounted to 76.56 and the remaining $23.44 \%$ influenced by other variables.

d. From the test results showed that $\mathrm{t}$ table with $\mathrm{I} \pm=$ $5 \%$ to test the two parties (df) $=\mathrm{n}-2$ is 0.235 from the calculation results obtained $t>t$ table or 1.072> 0.235 , then Ho is rejected, Ha acceptable means coefficient significant correlation between variables $\mathrm{X}$ (self-control) to variable $\mathrm{Y}$ (consumer behavior).

Based on the interpretation of research data shows that there are a very strong influence among the controls themselves against consumer behavior. Selfcontrol has functions such as: limiting one's attention to others, limiting one's desire to control others, limiting themselves to negative behavior and helping someone in meeting their needs in a balanced way. And in accordance with the results of the study, it can be concluded if someone is able to control spending by fighting the desire to spend excessively/extravagantly not based on needs so that self-control is related and also influences consumptive behavior. This means that if student self-control increases, the consumptive behavior of students will decrease.

Student consumptive behavior Guidance and counselling of Christian universities Indonesian is actually already good, but in managing themselves students are expected to be able to make a list of habits or behavior s that they want to control such as shopping for goods that are not in accordance with needs, eating at the mall and watching at the cinema, students are expected to ask for advice from parents and other closest people who are truly able to filter out the habit factors that are less useful. With the good self-control, guidance and counselling students are able to respond to offers and invitations that do not become their life's necessities.

\section{CONCLUSION}

Based on a simple regression test results, obtained by the equation $\mathrm{Y}=49.40$ to 0.109 . This equation shows that the coefficient value of self-control influence of $\mathrm{a}=49.40$ means that when self-control increases, the consumer behavior decreased by $\mathrm{b}=$ 0.109 at 49,40. Analisis constant correlation coefficient, $\mathrm{r} 0.84$ result is in the interval 0.80 to 1.00 , which means self-control influence on consumer behavior is very strong. Based on the calculation coefficient of determination (KD) obtained yield was $76.56 \%$, which indicates self-control variables contribute in consumer behavior amounted to 76.56 and the remaining $23.44 \%$ influenced by other variables. From the test results showed that $\mathrm{t}$ table with $\hat{\mathrm{I}} \pm=5 \%$ to test the two parties ( $\mathrm{df})=\mathrm{n}-2$ is 0.235 from the calculation results obtained $t>t$ table or $1,072>0.235$ then $\mathrm{Ho}$ is rejected, the Ha received means a significant correlation coefficient between variables $\mathrm{X}$ (selfcontrol) to variable $\mathrm{Y}$ (consumer behavior). Selfcontrol variables influence $76 \%$ of the consumer behavior at the Indonesian Christian University students and the rest influenced by other factors, then to all students at any university are advised to keep improving control of himself against the consumer behavior of students. 


\section{REFERENCES}

1. Andorfer, V.A., Liebe, U., 2013. Consumer behavior in moral markets. On the relevance of identity, justice beliefs, social norms, status, and trust in ethical consumption. Eur. Sociol. Rev. https://doi.org/10.1093/esr/jct014

2. Averill, J.R., 1973. Personal control over aversive stimuli and its relationship to stress. Psychol. Bull. https://doi.org/10.1037/h0034845

3. Brown, C., 2008. Developmental psychology, Developmental https://doi.org/10.4135/9781446214633

4. Cofer, C.N., 1965. Psychological Review. Am. Psychol. https://doi.org/10.1037/h0021465

5. Creswell, J.W., 2012. Research Design Qualitative,Quantitative, and Mixed Second Edition.

6. De Mooij, M., 2019. Consumer behavior and culture: consequences for global marketing and advertising. SAGE Publications Limited.

7. Glanz, K., Rimer, B.K., Viswanath, K., 2014. Health Behavior : Theory, Research, and Practice. Heal. Behav. Theory, Res. Pract. https://doi.org/10.7326/0003-4819-116-4-350_1

8. Gul, F., Pesendorfer, W., 2004. Self-control and the theory of consumption. Econometrica. https://doi.org/10.1111/j.1468-

0262.2004.00480.x
9. Håkansson, J., 2011. Developmental psychology, Developmental Psychology. https://doi.org/10.5005/jp/books/14190_13

10. Hurlock E., 2012. Development psychology, Handbook of research methods for studying daily life.

11. Paraswati, D. M., 1997. Korelasi antara Perilaku Konsumtif dengan Status Ekonomi Sosial Pembantu Rumah Tangga di Perumahan Perkotaan

12. Pretty, J., 2013. The Consumption of a Finite Planet: Well-Being, Convergence, Divergence and the Nascent Green Economy. Environ. Resour. Econ. https://doi.org/10.1007/s10640013-9680

13. Saito, F., 2009. Consumer behavior, Consumer Behavior. https://doi.org/10.5005/jp/books/11120_9

14. Sugiyono, 2016. Metode Penelitian Pendidikan Pendekatan Kuantitatif, Kualitatif, dan R\&D. Alfabeta, Bandung.

15. Sugiyono, 2010. Metode Penelitian Bisnis. Alfabeta, bandung.

16. Thaler, R., 1980. Toward a positive theory of consumer choice. J. Econ. Behav. Organ. https://doi.org/10.1016/0167-2681(80)90051-7

17. Torrance, E.P., Brehm, J.W., 1968. A Theory of Psychological Reactance. Am. J. Psychol. https://doi.org/10.2307/1420824 